\title{
Political Discourse: The Modality in Donald J. Trump's Speech in Riyadh Summit 2017
}

\author{
Prafina Yunisda \\ Universitas Negeri Surabaya \\ Surabaya, Indonesia \\ Prafinayunisda@mhs.unesa.ac.id
}

\author{
Ahmad Yusuf Firmansyah \\ Universitas Negeri Surabaya \\ Surabaya, Indonesia \\ Ahmadyusuf.18037@mhs.unesa.ac.id
}

\begin{abstract}
In search of the use of Modality in supporting a political speech and for revealing the tendencies behind it, therefore it examines Donald Trump's speeches using Types of Modality (Deontic and Epistemic modal) theory and Power, Identification and Manipulation (PIMI) model theory under Critical Discourse Analysis (CDA) approach. The study implements qualitative method consisting of description and the data are reported in words. As the result, Donald J. Trump uses all type of Modality of Deontic modal (permission and obligation) and Epistemic modal (probability/possibility). The aspects of Permission, obligation, and probability or possibility work in showing the idea of power, ideology, and manipulation. The context support Donald J. Trump speech in his Modality expression to promote against Terrorism intervening Middle East conflicts. Furthermore, the researcher is expected that this tool can be implemented in broader analysis and result in political discourse. The researcher also opens for further study that related to this topic in increasing the critical thinking of the readers, and adding more discussion in language and politics. It is also expected in the future that linguistic study can be a tool of transparency in political field especially in Indonesia.
\end{abstract}

Keywords-modality, auxiliary modal, deontic modal, epistemic modal, pimi model, cda, and political discourse.

\section{INTRODUCTION}

Language is the greatest tool of Politics. In implementing politic in public and private area, it cannot be denied that Language carries and contains its features that can reveal many extended and intended meaning inside political speech or debate. In learning more about it, Critical Discourse Analysis (CDA) is a necessary tool from Language discipline in conducting and analyzing in detail about some specific tendencies inside a political speech.

In this study, the researcher chooses Donald J. Trump as the recent President of United State who doing a speech in Riyadh Summit 2017. Flashing back from the Trump's controversial issues and policies dealing with Muslim countries and the Islam phobia issue, Donald J. Trump has a delicate and contra speech in Riyadh Summit that is held in Saudi Arabia in front of many Islamic countries' leaders. The speech shows a different performance of Trump that is previously very cold and contra towards Muslims and Muslim countries even proclaims huge and controversial policies which does not pro Muslim community. In this speech, he as the representative of US offers a huge cooperation in Economy, especially with the host country, Saudi Arabia. The second aim is to build cooperation in against Terrorism. US also positions as a country that is ready in front line in defending and supporting Muslim countries in defeating Terrorism or Radicalism. This kind of presentation that displays a 'different' Donald J. Trump with the preceding one, it eagers the researcher to look deeper about what are the tendencies yet intended aim or meaning inside the through the lenses of language discipline.

By selecting the use of Modal Auxiliary, researcher categorizing it into type of Modality according to Muria [1], Cruse [3], Kreidler [7], Palmer [10], Saeed [11] to make it more specific and clear in analyzing it, then completes it with Power, Ideology, and Manipulation Identification (PIMI) model, which is a new integrative, problem-oriented analytical tool for the systematic analysis of political discourse, created by adapting the theories and methods of Critical Discourse Analysis (CDA) which has been built on the basis of two existing analytical models [2] [14].

PIMI model is a CDA tool that can expose the social knowledge such as, Power, Ideology, and Manipulation through several levels of analysis from Pragmatics, Semantics, and Syntax level. The model is built up in independent, selfcontained levels, where all levels can be treated separately and can also be combined [13]. Seeing from the statement above, the researcher picks one level in Pragmatics as the classification of Modality is also seen pragmatically. It is applicable and suitable because Pragmatics in meaning is a Language with context, where Politics also works contextually moreover in this study case.

Seeing from the previous study done by Lillian [9], she categorizes the use of Modality into Epistemic and Deontic Modal from two different books with different authors. The researcher chooses the data with the significance gap of type of Modality use, to analyze the intended meaning using theory of Manipulative and Persuasive Discourse as the supporting theories. In the discussion and result of the study, the researcher can prove the use of Modality can work in finding Persuasion and Manipulation by using two combinations of theories instead as it is mentioned above.

The other associated research is conducted by Surjowati [12], which aims to identify the manifestation of authority and ideology through Sydney Morning Herald's choice of modality as the source of information. It uses CDA theory by Fairclough and concept of Modality by Bybee and Frawley. The result of 
this study can show that the use of Modality can contain Power and Ideology even though explained in short explanation.

There is a study done by Winiharti [15] dealing with type of Modality that only explaining in detail about the difference of Epistemic and Deontic Modal. The other study is done by Vadai, [13] that only introduces the theory of PIMI Model, the development of the theory, and the description of it. From the first two studies done by Lillian and Surjowati, the researcher of this study try to enlarge and prove more in detail about the discussion and result using combination of theories between Modality and CDA. Being inspired by the study done by Lillian [9], the researcher wants to support and improve this discussion area by combining the theory of type of Modality (Deontic and Epistemic modal) by Muria [1], Cruse [3], Kreidler [7], Palmer [10], Saeed [11] and the theory of PIMI Model as CDA tool by Fairclough [4] [5], Chilton \& Schaffiner [2], van Dijk [14] on Pragmatics level to gain broader and detail analysis and result as context in supporting Modality expression and also reveal the tendencies of the speaker in doing his political speech.

The previous studies have same points such as, Modality, Deontic and Epistemic Modality, Ideology, Manipulation and PIMI Model. The objectives of the study are the written one and the spoken one. The written one is from books and newspaper. On this study, the subject is Donald J. Trump speech in Riyadh Summit 2017. It concerns on the use of Modality, the contexts behind it, and how the contexts can support his Modality expression. Based on the background stated previously, there will be some problems to be discussed, they are, 1) What are the Modality used by Donald J. Trump in his speech in Riyadh summit 2017? 2) How do the contexts support Donald J. Trump in using those Modalities

\section{METHODS}

The research conducts a Qualitative research. The Subject of the Study was the recent US President, Donald J. Trump. The setting was in Riyadh Summit 2017 in front of many Muslim leaders shortly after his controversial issues regarding Muslims and Muslim majority countries were launched. The data of this study were the sentences and clauses containing Modality which had been categorized. The source of data was transcript of the political speech done by Donald J. Trump in Riyadh Summit 2017. This research utilized records of assessment and the culture of materials to obtain the information as the information are obtained from script analysis. Furthermore, paperwork was a method used to determine the variable in the form of notes, transcripts, articles, etc.

\section{RESULTS AND DISCUSSION}

\section{A. Modality of Permission}

\section{Datum 1}

There can be no coexistent with this violence. There can be no tolerating it, no accepting it, no excusing it, and no ignoring it.
From the sentence above, the speaker tries to declare bad things or consequences that will happen by the letting the act of Extremists and Terrorism spreads well. The words 'there can be no tolerating it, no accepting it, no excusing it, and no ignoring it', it clearly shows that the speaker does not give any permission towards act of Terrorism. In the other words, the speaker means not to allow all kind of good treats toward Terrorists or Terrorism.

\section{Datum 2}

When we look upon the streams of innocent blood soaked into the ancient ground, we cannot see the faith or sect or tribe of the victims - we see only that they were children of God whose deaths are an insult to all that is holy. But we can only overcome this evil if the forces of good are united and strong - and if everyone in this room does their fair share and fulfills their part of the burden. Terrorism has spread across the world. But the nations of the Middle East cannot wait for American power to crush this enemy for them.

From the words 'we can only overcome this evil if the forces of good are united and strong', it reflects the speaker's permission to be supported well in defeating the evil or any kind of bad acts, which is here purposed to a Terrorism act. The other sign of permission that is more obvious is on the part, "the Middle East cannot wait for America power to crush this enemy for them'.

\section{Datum 3}

The nations of the Middle East will have to decide what kind of future they want for themselves, for their countries, and for their children, it is a choice between two futures - and it is a choice America cannot make for you

The words 'America cannot make for you' is a sign of permission delivering in negative way. The words mean that America does not permit themselves to make a decision for the future of Middle East countries before they start it first.

\section{B. Modality of Obligation}

\section{Datum 4}

Muslim nations must be willing to take on burden, if we are going to defeat terrorism and send its wicked ideology into oblivion.

From the words above, the speaker obligates the Muslim nations to be ready with the burden they further achieve in defeating Terrorism.

\section{Datum 5}

As we deny terrorist organizations control of territory and populations, we must also strip them of their access to funds. We must cut off the financial channels that let ISIS sell oil, let extremists pay their fighters, and help terrorists smuggle their reinforcements.

On this part, the speaker obligates all the related nations to cut off the financial aid towards Terrorism. 


\section{Datum 6}

We must stop what they are doing to inspire, because they do nothing to inspire, but kill. We are having a very profound effect if you look at what's been happening recently.

On this section, the speaker gives a command to all the related individuals and nations to stop the act of Terrorism. The modal 'must' indicates an obligation in types of Modality.

\section{Modality of Probability/Possibility}

\section{Datum 7}

Yesterday, we signed historic agreements with the Kingdom that will invest almost $\$ 400$ billion in our two countries and create many thousands of jobs in America and Saudi Arabia.

The speaker shares a possibility type of Modality for this part of speech. He shows a possibility of something to be done by Kingdom of Saudi Arabia, by the speaker saying that they will do an investment almost $\$ 400$ billion to America. The speaker here is also kind of announcing something to the audiences.

\section{Datum 8}

If we do act against this organized terror, then we know what will happen and what will be in the end of the day.

From the words above, the speaker shows a probability and possibility about what will happen in the future if all the countries present in the summit united with America in against Terrorism. The statement 'we know what will happen' is declared in positive way that it means if all the united nations are really keen on against Terrorism, then the bright future will be guaranteed and tasted.

\section{Datum 9}

I am proud to announce that the nations here today will be signing an agreement to prevent the financing of Terrorism.

The speaker here conducts a possibility of type of Modality by saying 'here today will be signing an agreement to prevent the financing of Terrorism'. He declares a possibility of something to be happened, and in this case isabout the possibility of all the present countries to sign an agreement in preventing the financial support for Terrorism.

As what Fowler [6] argues that the connection of two modal meanings of obligation and permission with the power is obvious. Here is the further analysis using PIMI Modal in analyzing in detail about the contexts and the tendencies from each selected datum displayed on the preceding section.

\section{Power}

Referring to the first datum, the speaker shares a truth claim by delivering such as strong and angelic form of words inagainst Terrorism. A truth claim is a sign of power in PIMI Model. For referring to datum 2, America try to say that they do not permit any Middle East countries to wait for them to support their movement against all the enemies, US requests to the Middle East to start their act on the first movement, by having good or conducive internal relationship inside their each country for the first. The sentence, 'the nations of the Middle East cannot wait for American power to crush this enemy for them' indicates a request to not wait for America to support or do the action. It conducts US power to rule Middle East countries through giving permission to them. Referring to datum 3, an announcement towards the audiences present in the summit, based on power identification model, it cannot be denied that an announcement also a sign of power. On this part, the speaker as the US President shows a power in announcing that kind of statement above. When the audiences wait for an information or statement from the speaker, it proves that the speaker holds the higher position and authority where the listeners need to listen and know from him.

Discussing on datum 4, the speaker speaking at this part of speech also indirectly shows a truth claim that shows power. Bring up to datum 5, not only by commanding the audiences (the presented countries), but the speaker also gives a threat towards Terrorists about their financial aid that will be gone. A command here reflects power done by the speaker. Based on datum 6 , by giving a command and sharing a truth claim through the sentence above, the speaker shares a strong power.

Discussing on datum 7, In this case, the speaker announces or informs the audiences that huge number of investment by Kingdom of Saudi Arabia. For some signs of a power, an announcement is one of the things that can expose it. In this case, the speaker shows a power in announcing something in form of possibility to invest huge number of dollars. Referring to datum 8 , the speaker also shares a truth claim shows power. Based on datum 9, From the words 'I am proud to announce' shows obviously that the speaker also announce something, where on this case is about informing the audiences if he totally believe that all the countries in the summit will work together with him (US) in stopping the financial aid for Terrorism. By delivering an announcement, it is directly proved that power is found in this part of the speech.

\section{E. Ideology}

Referring to datum 1, a truth claim is able to influence the audiences in the way they think and see something. By giving a truth claim, the speaker unconsciously and automatically plays role as the seer of the future that also contribute a strong effect towards the audiences' point of view. Truth claim also shows the speaker's belief or ideology that also represents Americans' ideology towards an act of Terrorism which is viewed so negatively.

Speaking of datum 2, on the statement, 'But we can only overcome this evil if the forces of good are united and strong', the speaker shows a truth claim by giving the value of goodness can overcome an evil, it aimed to the case in defeating Terrorism or any other violent acts. It indirectly tells the speaker's ideology and obviously American ideology in dealing with battling against Terrorism or any kind of bad acts in many aspects.

Referring to datum 4, the speaker acts as the seer of future by uttering the words above, which is automatically shows the ideology dealing with Terrorism act. An ideology can be revealed by the use of truth claim that the speaker shares in the speech. Bringing up datum 5, by giving a threat, the speaker 
unconsciously shares his belief dealing with Terrorism. It opens the ideology of the speaker and his county towards Terrorism and ISIS as a movement that should be banned as soon as possible, even something that dealing with their financial matter.

Referring to datum 6 , the truth claim also shows the American ideology towards Terrorism as first enemy for them. An assertion done by the speaker can obviously reveal the ideology behind it which also belongs to certain group, country, or institution he represent. On this case, the speaker shows his ideology and his country's ideology towards Terrorism that is considered as really negative as some supporting groups or systems behind it.

Referring to datum 7, the speaker positions himself as the seer of the future on this case. It is proved by saying, "then we know what will happen and what will be in the end of the day'. A truth claim also indirectly can reveal the speaker and his country's ideology towards Terrorism, as truth claim is one of signs in investigating an ideology based on PIMI model.

\section{F. Manipulation}

Referring to datum 1, a kind of de-legitimation or promoting 'Their' bad act done in the speech also works as a manipulation act towards the audiences. The speaker tries to manipulate the audiences by portraying a Terrorism in negative way. Speaking to datum 2 , for all the angelic words that the speaker says, it portrays a positive self-presentation that is quite enough to show the speaker's manipulation towards the audiences.

Referring to datum 5, from the words, 'because they do nothing to inspire, but kill' it shows a negative 'other' presentation or de-legitimation from the speaker to the certain group which here is de-legitimation indicates to the Terrorists. A delegitimization is also a sign of a manipulation act that the speaker does in the speech.

In the use of Modality of Permission, Donald J. Trump is identified to use power, as the relation of Modality of permission and obligation (Deontic Modality) is obvious to power use. The essence of power is defined by Fowler [6] and van Dijk [14] as a kind of relationship in which asymmetry and control are inevitable. Majorly, the Modality of permission used by Donald Trump can show the ideology of the speaker dealing with Terrorism, Conflicts, and Humanity. Kress [8] says that ideology is various uses range from the notion of the system, values, or worldview of concepts to more contentious ones such as false consciousness or dominant ruling class thinking. It also represents the people yet country of the speaker in charge. The manipulation done by the speaker is also able to reveal from the selected data of Modality of permission.

From the data analysis above, power is identified in all types of Modality (permission, obligation, and possibility or probability). Fowler [6] says power is the capacity of people and organizations to regulate the behavior and material life of other people. Based on the permission type of Modality the speaker shares many truth claims and gives announcement that considered as signs of power. According to Saeed [11],
Modality type of permission deals with the power of someone else to allow someone else to do something, from the result above, the researcher finds that the speaker also tend to act as a seer of the future and tends to deliver some angelic words. Vadai [13] claims that the politician's access to data is privileged, he takes on the position of an omnipotent personality, the knower of the data, the seer of the future by stating his allegations of reality. By using expressive speech acts, this power position could be further emphasized. By giving the truth claim in against Terrorism, the speaker also giving a powerful speech towards the audiences, the speaker shares the truth claim by using some angelic words to give a sense of power in ruling the audiences. Those powerful sentences uttered by Donald J. Trump are directed to Terrorism issues. The speaker gives truth claim towards his act against Terrorism and he gives some announcements regarding Terrorism that he positions as the first enemy.

From the obligation part, the speaker dominantly obligates the audiences in against Terrorism. Saeed [11] argues that obligation type of Modality is concerned with what a person must do. It is quite obvious that Donald J. Trump in the speech tend to request and command all the present Muslim countries to stop the financial aid and fighting against them. By asking some requests and giving some commands, it is unquestionably that Donald J. Trump has a big influence as the speaker and shares a strong power dealing with countering Terrorism act. On the possibility or probability part of type of Modality, the speaker also gives many announcements that indicates power. Kreidler [7] states that epistemic modality deals with a particular proposal's likelihood, likelihood or impossibility. Palmer [10] claims that opportunity, necessity and prediction would be indicated by the significance of epistemic models. The announcement is majorly for countering Terrorism. It is clearly proved on this part of the speech, 'I am proud to announce that the nations here today will be signing an agreement to prevent the financing of Terrorism'.

The positive image of the speaker in giving the truth claim about something related to the conflict reflects the ideology of the speaker. It shows the speaker system of idea towards Middle East conflicts. It shows the speaker and Americans belief to take a part in Middle East conflict in order to end with beautiful way based on them. From all parts of type of Modality, the speaker gives the truth claims dealing with the conflict that all his request and command are guaranteed to be done. Vadai [13] argues that fundamentally, ideologies seem to reveal themselves in the form of representatives that generally appear in speeches as assertions or claims of truth. The positive self-presentation that showing 'Our' good act and 'Their' bad act in giving opinion and making decision towards Middle East conflicts unconsciously shows the speaker system of idea. The system of idea dealing with humanity, war, and International affairs, it shows America's belief that has to speak in term of war, humanity, and conflict regarding to other countries, or considering as internal problem of other countries to intervene. 


\section{CONCLUSION}

The researcher draws some points of conclusion from the finding and debate in the past section. The first is Deontic Modal and Epistemic Modality used in the speech, it means that all obligation, permission, and probability or possibility is used the speech of Donald J. Trump. The second is Deontic modal with permission is dominantly used in the speech. The third is all the types of Modality (permission, obligation, and probability/possibility) are used in the speech indicates a power of the speaker by showing request, command, truth claims, and announcements. The fourth is Type of Modality of permission, obligation, and possibility/possibility can reveal the ideology of the speaker and show a manipulative act done by the speaker. It is proved by the dominant use of truth claims and positive selfimage that the speaker presents in the speech. The fifth is the use of Modality in Donald J. Trump speech can support his political speech in promoting against Terrorism and intervening the Middle East conflicts as what the issues is majorly found in the analysis of result in the study.

There are many theories and systems in linguistics instead of Modality that will be a good tool in CDA and Political Discourse. There are also many approaches instead of CDA that can be used for further study. It is suggested that the further study will use the combination theory and emphasize a better result. It is expected to be used as a reference for the further study. It can also be helpful in Indonesia for political and language work.

\section{REFERENCES}

[1] Celce-Muria, M. and Diane Larsen-Freeman. (1999). The Grammar Book: An ESL/EFL Teacher's Course. 2nd edn. Los Angeles: Heinle\&Heinle Publishers.

[2] Chilton, P., \&Schäffner, C. (1997) Discourse and politics. In T.A. van Dijk (Ed.), Discourse as social interaction - Discourse studies: A multidisciplinary introduction - Vol. 2. London: SAGE Publications. pp. 206-229.

[3] Cruse, D.A. (2004).Meaning in Language: An Introduction to Semantics and Pragmatics. 2nd end. Oxford: Oxford University Press.

[4] Fairclough, N. (2001) Language and Power (second edition). Harlow: Longman.

[5] Fairclough, N., \&Wodak, R. (1996) Critical discourse analysis. In T. A Van Dijk (Ed.), Discourse as social interaction - Discourse studies: A multidisciplinary introduction - Vol. 2. London: SAGE Publications. pp. 259-283.

[6] Fowler, R. (1985) Power. In T. A. van Dijk (Ed.), Handbook of discourse analysis - Discourse in society - Vol. 4. London: Academic Press. pp. 61-82.

[7] Kreidler, C. W. (1998). Introducing English Semantics. London: Routledge.

[8] Kress, G. (1985) Ideological structures in discourse. In T. A. van Dijk (Ed.), Handbook of discourse analysis - Discourse analysis in society Vol. 4. London: Academic Press. pp. 27-43

[9] Lillian, D. L. (2008).Modality, persuasion and manipulation in Canadian conservative discourse. Critical Approaches to Discourse Analysis across Disciplines, 2(1), 1-16.

[10] Palmer, F. R. (1986). Mood and modality.Cambridge University Press.

[11] Saeed, J. L. (2003). Semantics. 2nd ed. Oxford: Blackwell Publishing.

[12] Surjowati, R. (2017). Revealing Power And Ideology Through Modality Expressions In Australian Newspaper Reporting Jis's Pedophilia. In Proceedings of International Seminar Prasasti III: Current Research in Linguistics. Solo: Pascasarjana Universitas Sebelas Maret pp 630-635.

[13] Vadai, K. (2016). Critical discourse analysis in progress: the power, ideology and manipulation identification (PIMI) model. AlkalmazottNyelvtudomány, 16.

[14] Van Dijk, T. A. (2006) Discourse and manipulation. In Discourse \& Society. London: Thousand Oaks. pp. 359-383.

[15] Winiharti, M. (2012). The Difference Between Modal Verbs In Deontic And Epistemic Modality. Journal of Humaniora language, people, art, and communication studies vol. 3 no. 2. Jakarta: Bina Nusantara University. pp 532-539. 